\section{Evaluation of the Serum Levels of Uric Acid and C-reactive Protein in Isolated Coronary Artery Ectasia}

\author{
Aydın Rodi Tosu1, Mustafa Yurtdaş², Mahmut Özdemir², Murat Selçuk², Nesim Aladağ2, \\ Yemlihan Ceylan², Tayyar Akbulut ${ }^{2}$, Yüksel Kaya ${ }^{3}$ \\ ${ }^{1}$ Mehmet Akif Ersoy Thoracic and Cardiovascular Surgery Training and Research Hospital, Clinic of Cardiology, \\ İstanbul, Turkey \\ 2 Van Regional Training and Research Hospital, Clinic of Cardiology, Van, Turkey \\ ${ }^{3}$ Kafkas University Faculty of Medicine, Department of Cardiology, Kars, Turkey
}

\begin{abstract}
Introduction: Isolated coronary artery ectasia (CAE) is defined as the arterial enlargement of 1.5 times or more compared to the adjacent normal arterial portion without significant coronary artery stenosis. Although the exact cause is not clearly known, increased inflammation is the most responsible factor in pathogenesis of CAE. Serum uric acid (SUA) and C-reactive protein (CRP) are the most widely used markers of inflammation. In this study, we aimed to investigate the possible association of isolated CAE with SUA and CRP levels.

Patients and Methods: In this study, 4.600 patients undergoing coronary angiography in our hospital due to a known or suspected ischemic heart disease between January 2011 and August 2012 were retrospectively evaluated. Following the exclusion criteria, our study population consisted of $110(63.6 \%$ males, mean age: $58.1 \pm 9.5$ years) isolated CAE patients, 110 patients (63.6\% males, mean age: $55.2 .4 \pm 2.3$ years) with coronary artery diseases (CAD) who were matched with this group in age, gender and cardiovascular risk factors (body mass index, hypertension, diabetes, hyperlipidemia and smoking status) and 100 patients with angiographically normal coronary arteries (51.0\% males; mean age: $57.6 \pm 10.1$ years). Basal SUA and CRP are routinely measured in our clinic before the coronary angiography.

Results: Serum level of uric acid did not show a significant difference between CAE and CAD groups (6.5 \pm 0.5 $\mathrm{mg} / \mathrm{dL}$ and $6.4 \pm 0.5 \mathrm{mg} / \mathrm{dL} ; \mathrm{p}>0.05)$, while this value was found significantly higher in both groups compared to the controls $(5.1 \pm 0.5 \mathrm{mg} / \mathrm{dL} ; \mathrm{p}<0.001)$. Similarly, there was not a significant difference between CAE and CAD groups in terms of the serum level of CRP $(1.8 \pm 0.0 \mathrm{mg} / \mathrm{dL}$ and $1.7 \pm 0.3 \mathrm{mg} / \mathrm{dL} ; \mathrm{p}>0.05)$, while CRP values were significantly higher in both groups compared to the controls $(1.1 \pm 0.4 \mathrm{mg} / \mathrm{dL} ; \mathrm{p}<0.001)$.

Conclusion: We found that levels of SUA and CRP were higher in the patients with CAE than in subjects with normal coronary artery, but no significant different was found compared to patients with CAD. These data suggest that both $\mathrm{CAE}$ and CAD shared common pathophysiological mechanisms.
\end{abstract}

Key Words: Coronary ectasia; coronary artery disease; serum uric acid; C-reactive protein

\section{İzole Koroner Arter Ektazilerinde Serum Ürik Asit ve C-reaktif Protein Düzeylerinin Değerlendirilmesi}

\section{ÖZET}

Giriş: İzole koroner arter ektazileri (KAE) ciddi koroner arter darlığı olmaksızın normal koroner arter bölgesine göre 1,5 kat veya daha fazla arter genişlemesi olarak tanımlanır. KAE'nin nedeni tam olarak bilinmemekle beraber patogenezinde en çok artmış inflamasyon suçlanmaktadır. Serum ürik asit (SÜA) ve C-reaktif protein (CRP) inflamasyonun yaygın kullanılan belirteçleridir. Biz bu çalışmada SÜA ve CRP ile izole KAE arasındaki muhtemel ilişkiyi araştırdık.

Hastalar ve Yöntem: Bu çalışmada bilinen veya süpheli iskemik kalp hastalığı nedeniyle Ocak 2011-Ağustos 2012 tarihleri arasında hastanemizde koroner anjiyografi yapılan 4600 hasta geriye dönük olarak değerlendirildi.

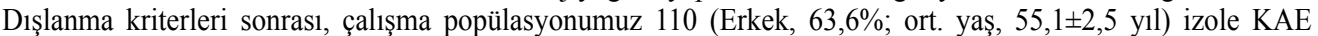
hastası, bu grupla yaş, cinsiyet ve kardiyovasküler risk faktörleri (vücut kütle indeksi, hipertansiyon, diyabet, hiperlipidemi ve sigara içiciliği) olarak eşlenmiş 110 koroner arter hastası (KAH) (Erkek, 63,6\%, ort. yaş,

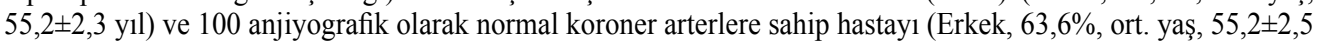
y1l) kapsadi.

Bulgular: Serum ürik asit düzeyi KAE ve KAH grupları arasında anlamlı fark göstermezken $(6,5 \pm 0,5 \mathrm{mg} / \mathrm{dl}$ ve $6,4 \pm 0,5 \mathrm{mg} / \mathrm{dl} ; \mathrm{p}>0,05)$, kontrol grubuna $(5,1 \pm 0,5 \mathrm{mg} / \mathrm{dl})$ göre her iki grupta da anlamlı derecede yüksek bulundu $(\mathrm{p}<0,001)$. Benzer şekilde serum CRP düzeyi KAE ve KAH grupları arasında anlamlı fark göstermezken $(1,8 \pm 0,0$ $\mathrm{mg} / \mathrm{dl}$ ve $1,7 \pm 0,3 \mathrm{mg} / \mathrm{dl} ; \mathrm{p}>0,05)$, kontrol grubuna $(1,1 \pm 0,4 \mathrm{mg} / \mathrm{dl})$ göre her iki grupta da anlamlı derecede yüksek bulundu $(\mathrm{p}<0,01)$.

Sonuç: KAE olanlarda, normal koroner arterlere sahip olanlar ile karşılaştırıldığında, SÜA ve CRP seviyelerinin yüksek olduğunu ancak KAH ile karşılaştırıldığında anlamlı farklılık olmadığını saptadık. Bu veriler, KAE ve KAH'in ortak patofizyolojik mekanizmaya sahip olduğunu düşündürmektedir.

Anahtar Kelimeler: Koroner ektazi; koroner arter hastalı̆̆ı; serum ürik asit; C-reaktif protein

\section{Correspondence \\ Mahmut Özdemir \\ E-mail: dragit56@hotmail.com \\ Submitted: 28.04 .2014 \\ Accepted : 18.06.2014}

@Copyright 2014 by Koşuyolu Heart Journal - Available on-line at www.kosuyolukalpdergisi.com 


\section{INTRODUCTION}

Coronary artery ectasia (CAE), an abnormality of the coronary anatomy, has been identified as an enlarged artery luminal diameter that is 1.5 or more times greater than the diameter of the adjacent normal portion of the artery(1). Isolated CAE is defined as coronary artery ectasia developed without a significant coronary artery stenosis. In the previous studies, CAE was shown to be associated with the increased risk for cardiovascular events $(2)$. The underlying mechanisms responsible for ectasia formation are not clearly known, but previous studies have reported that CAE may be a form of atherosclerosis and has more potent inflammatory properties than normal vessels $(3,4)$.

Uric acid is the final breakdown product of purine matabolism. Numerous studies have demonstrated that serum level of uric acid (SUA) is an important and independent risk factor for development of cardiovascular diseases (5-7). Significant correlations have been reported between SUA and the conditions inducing or accelerating atherosclerosis such as various inflammatory markers, oxidative stress and endothelial dysfunction(8-11).

$\mathrm{C}$-reactive protein (CRP) is a member of the pentraxin groups, consisting from the discoid pentameric structures. While initially it was believed to be arised merely from the liver, later it was demonstrated to be produced also in adipocytes, atherosclerotic lesions, coronary artery smooth cells and aortic endothelial cells(12-15). Increased CRP, as a significant marker of inflammation, is known to be correlated with endothelial dysfunction and atherosclerotic formation(16).

Given that the mechanism of CAE to be associated with an increased inflammation and CRP and SUA are markers of inflammation, we hypothesized that increased CRP and SUA might be associated with the presence of isolated CAE. We evaluated this hypothesis in a real world population of patients who underwent coronary angiography for suspected or known ischemic heart disease.

\section{PATIENTS and METHODS}

\section{Patient Selection}

Four thousand six hundred patients who underwent coronary angiography due to suspected or known ischemic heart disease between January 2011 and August 2012 were retrospectively evaluated. A hundred and ten patients $(2.9 \%)$ with CAE were identified (group 1, 63.6\% male; mean age 55.1 \pm 2.5 ). A hundred and ten consecutive patients matched with CAE in terms of age, sex and cardiovascular risk factors $(63.6 \%$ male, mean age 55.2 \pm 2.3 ) were assigned to group 2 , and a hundred patients with angiographically normal coronary arteries constituted the control group (group 3, 51\% male; mean age 55.2 \pm 2.5 ).

Presence of hypertension was considered as a systolic blood pressure of $140 \mathrm{mmHg}$ or higher, a diastolic pressure of $90 \mathrm{mmHg}$ or higher or using antihypertensive medications. Diabetes mellitus was defined as having a fasting blood glucose of $126 \mathrm{mg} / \mathrm{dL}$ or higher or currently receiving antidiabetic therapy or being on diet.
Typical angina or a positive or suspected outcome yielded by one of the non-invasive methods for coronary arterial examination was defined as an indication for coronary angiography. Body mass index (BMI), glucose, triglycerides, high-density lipoprotein cholesterol (HDL) and low-density lipoprotein cholesterol (LDL) of the patients were measured. Smoking habit was determined. Our study was approved by the local ethics committee.

\section{Evaluation of Coronary Artery Ectasia and Coronary Artery Disease}

Coronary angiography was carried out according to Judkins technique with $6 \mathrm{Fr}$ right and left heart catheters without nitroglycerin use. Angiograms were recorded into the digital media with a rate of 25 frame/milliseconds and evaluated by two angiography specialists who were unaware of the patient's data. Coronary artery ectasia was defined as the enlargement of coronary artery by 1.5 times or more compared to the adjacent normal coronary artery. Stenosis of $20 \%$ or more in at least one vessel was defined as coronary artery disease (CAD).

\section{Laboratory}

Blood samples are collected from antecubital vein by an atraumatic puncture prior to the coronary angiography and sent to the laboratory for analysis within 1 hour after collection.

\section{Definition of the Serum Level of C-reactive Protein}

Blood samples were collected from one of the antecubital veins without venous stasis and taken into tubes which did not contain sterile and anticoagulant. Serum CRP concentrations were measured with nephelometric Siemens Dade-Behring NBII device (Siemens Healtycare Diagnostics Products GmBH, Marburg/Germany).

\section{Definition of the Serum Level of Uric Acid}

Blood samples were collected from the patients with a fasting for one night prior to coronary angiography and then the samples were centrifuged at $3000 \mathrm{~g}$ for 10 minutes. The samples were kept at $-70{ }^{\circ} \mathrm{C}$ and then analyzed. Serum level of uric acid was measured in a clinical chemistry autoanalyzer (Modular P, Roche Diagnostics, Germany-Switzerland) using enzymatic colorimetric assay.

\section{Statistical Method}

Continuous variables are expressed as mean \pm SD. Categorical variables are expressed as percentages. Adequacy of all parameters to normal distribution, was tested by using Kolmogorov-Smirnov Test. To compare parametric continuous variables, the Student's t test or ANOVA were used; to compare nonparametric continuous variables, the Mann-Whitney $U$ or Kruskal-Wallis were used; to compare categorical variables, the chi-square test was used. Effect level was analyzed using logistics regression and Receiver Operating Characteristics (ROC) curve. Pearson and Spearman correlation analyses were used for the correlation analysis. Two-tailed $p$ values $<0.05$ were considered to indicate statistical significance. Statistical analyses were performed using SPSS, version 20.0 for Windows. 


\section{RESULTS}

Among 320 patients (mean age 55.1 $\pm 2.6 ; 59.4 \%$ male), SUA ranged from 3 to $7.6 \mathrm{mg} / \mathrm{dL}$ (mean $6 \pm 0.5 \mathrm{mg} / \mathrm{dL}$ ) and CRP ranged from 0.5 to $2.4 \mathrm{mg} / \mathrm{dL}$ (mean $1.3 \pm 0.2 \mathrm{mg} / \mathrm{dL}$ ). The baseline characteristics of all groups are summarized in Table 1.

In $\mathrm{CAD}$ group, $\mathrm{CAD}$ was identified to affect the left anterior descending artery the most $(72.5 \%)$, followed by circumflex $(61.7 \%)$ and right coronary artery (55.5\%). Additionally, CAD was found to have a tendency to affect 1-vessel (57\%), 2-vessel $(33 \%)$, and 3 -vessel $(10 \%)$, respectively.

Uric acid and CRP values were significantly lower $(\mathrm{p}<0.05)$ in normal coronary artery patients compared to patients with CAE and CAD. Uric acid and CRP values were similar in the patients with CAE and CAD (p>0.05) (Table 2, Figure 1).

In the one-variable logistic regression analysis, uric acid value created a significant model and increased the odds for coronary ectasy by 2.583 folds $(147-45314)(\mathrm{p}=0.000<0.001)$. In the one-variable logistic regression analysis, CRP value created a significant model and increased the odds for coronary ectasy by 1.187 folds $(182-7735)(\mathrm{p}<0.001)$ (Table 3$)$.

In multivariable logistic regression, effect of uric acid was found to be significant, while effect of the CRP level was not significant. Uric acid value was an independent risk factor (Table 4).

A positive correlation was found between the levels of CRP and uric acid (Figure 2).

The most effective cut-off value distinguishing a patient with coronary ectasia from a normal coronary artery patient was $1.5 \mathrm{mg} /$ $\mathrm{dL}$ for a CRP level (Area under curve $=0.930, \mathrm{p}<0.001$ ) (Table 5).

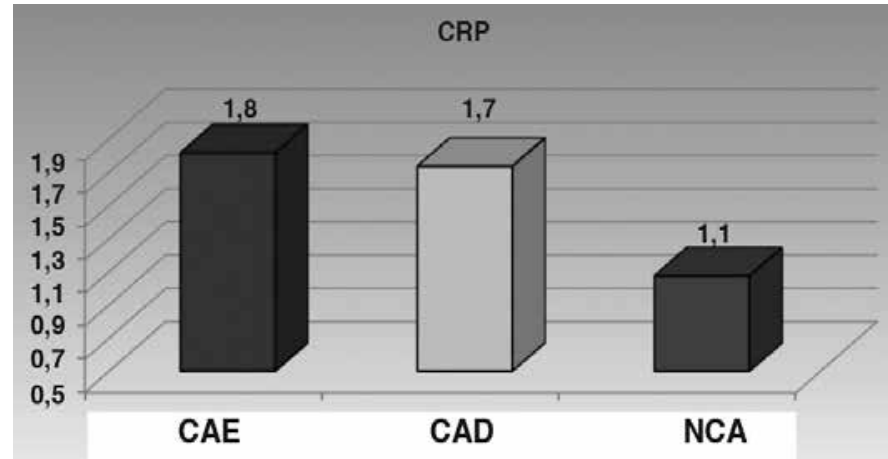

Figure 1. C-reactive protein levels in all groups, CAD: Coronary artery disease, CAE: Coronary artery ectasia, CRP: C-reactive protein, NCA: Normal coronary artery

\begin{tabular}{lcc}
\hline \hline & & Uric Acid \\
\hline \multirow{2}{*}{ CRP } & $\mathrm{r}$ & 0,707 \\
\cline { 2 - 3 } & $\mathrm{p}$ & 0,000 \\
\hline
\end{tabular}

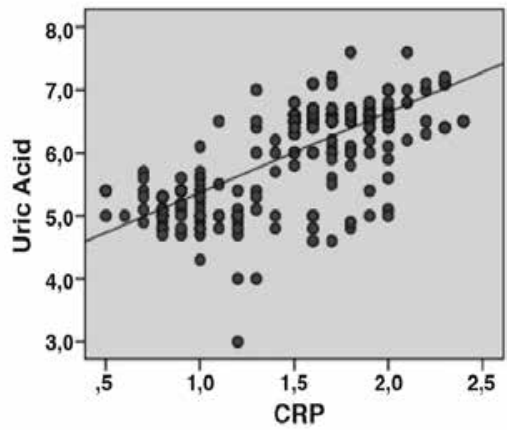

Figure 2. Positive correlation between uric acid and C-reactive protein levels, CRP: C-reactive protein

\begin{tabular}{|c|c|c|c|c|}
\hline & $\begin{array}{l}\text { Coronary ectasy } \\
\text { Mean } \pm \text { SD/n \% }\end{array}$ & $\begin{array}{l}\text { Coronary artery patients } \\
\text { Mean } \pm \text { SD/n \% }\end{array}$ & $\begin{array}{l}\text { Normal coronary patients } \\
\text { Mean } \pm \text { SD/n \% }\end{array}$ & $\mathbf{p}$ \\
\hline Age & $55.1 \pm 2.5$ & $55.2 \pm 2.3$ & $55.2 \pm 2.5$ & 0.946 \\
\hline $\begin{array}{l}\text { Gender male } \\
\text { female }\end{array}$ & $\begin{array}{l}70 \% 63.6 \\
40 \% 36.4\end{array}$ & $\begin{array}{l}70 \% 63.6 \\
40 \% 36.4\end{array}$ & $\begin{array}{l}51 \% 51 \\
49 \% 49\end{array}$ & 0.102 \\
\hline $\begin{array}{l}\text { Smoker } \\
\text { Non-smoker }\end{array}$ & $\begin{array}{l}31 \% 28.2 \\
79 \% 71.8\end{array}$ & $\begin{array}{l}41 \% 37.3 \\
69 \% 62.7\end{array}$ & $\begin{array}{l}23 \% 23.0 \\
77 \% 77.0\end{array}$ & 0.071 \\
\hline $\mathrm{DM}$ & $28 \% 25.5$ & $34 \% 30.9$ & $37 \% 37.0$ & 0.195 \\
\hline BMI & $25.6 \pm 1.4$ & $25.6 \pm 1.4$ & $25.6 \pm 1.4$ & 0.998 \\
\hline HDL & $40.4 \pm 2.7$ & $39.9 \pm 3.3$ & $40.1 \pm 3.1$ & 0.669 \\
\hline LDL & $121.2 \pm 3.7$ & $119.1 \pm 14.8$ & $122.0 \pm 8.6$ & 0.195 \\
\hline
\end{tabular}

Results are expressed as mean \pm SD and percentage. (BMI: Body mass index, DM: Diabetes mellitus, HDL: High-density lipoprotein cholesterol, HT: Hypertension, LDL: Low-density lipoprotein cholesterol)

Table 2. Plasma uric acid and C-reactive protein (CRP) levels

\begin{tabular}{|c|c|c|c|c|}
\hline & $\begin{array}{l}\text { Coronary Ectasy } \\
\text { Mean } \pm \text { SD }\end{array}$ & $\begin{array}{l}\text { Coronary Artery Disease } \\
\text { Mean } \pm \text { SD }\end{array}$ & $\begin{array}{l}\text { Normal Coronary Artery } \\
\text { Mean } \pm \text { SD }\end{array}$ & $\mathbf{p}$ \\
\hline Uric acid & $6.5 \pm 0.5$ & $6.4 \pm 0.5$ & $5.1 \pm 0.5$ & $<0.0001$ \\
\hline
\end{tabular}


The most effective cut-off value distinguishing a patient with coronary ectasia from a normal coronary artery patient was $6 \mathrm{mg} / \mathrm{dL}$ for a level of uric acid (Area under curve $=0.995$ / $\mathrm{p}<0.001$ ) (Table 6).

\section{DISCUSSION}

In this study, we observed that both CAE and CAD patients had significantly higher levels of SUA and CRP than control subjects. Additionaly a greater baseline SUA value was independently associated with the presence of isolated CAE.

In the CASS (coronary artery surgery study), the largest study investigating coronary artery ectasy, CAE was found in 978 (4.9\%) of 20,087 patients(1). In another study with 3.900 patients examined by coronary angiography, CAE was observed by $5.3 \%(17)$. In our study, this rate was found as $2.9 \%$. Some of the possibilities for this discrepancy might be the definition of CAE and inclusion criteria being used and the different angiography indications of the patient population analyzed.

More than $50 \%$ ofCAE patients have coronary atherosclerosis, but occasionally CAE is seen in association with connective tissue disorders and vasculitides $(18,19)$. Therefore, this associaton supports the view of CAE to be a variant of CAD. CAE has been demonstrated to be related with increased cardiac morbidity and mortality by mechanisms such as coronary slow flow, coronary vasospasm, dissection and thrombus formation(18-20). Although the underlying mechanisms responsible for ectasia formation are not clearly known, previous studies have showed that inflammation and oxidative stress are closely associated with $\mathrm{CAE}(21-24)$. Additionally, It is well-known that elevated inflammatory markers, such as CRP, IL-6, TNF- $\alpha$ and MMP are related with the presence of $\mathrm{CAE}(23-25)$.

Uric acid is the final destruction product of purine metabolism. Thus, increased serum level of uric acid is a marker of increased oxidative stress and endothelial dysfunction. Allopurinol, which is a xanthine oxidase inhibitor used for treatment of hyperuricemia, was shown to improve brachial artery flow-related dilatation by decreasing oxidative stress, thus endothelial dysfunction(21). Furthermore, previous studies reported that the presence of CAE is associated with increased oxidative stress and endothelial dysfunction(22). In our study, we demonstrated that the level of SUA significantly increased in CAE patients, similar to CAD

$\begin{aligned} & \text { Table 3. One-variable analysis of the levels of uric acid and } \\
& \text { C-reactive protein }\end{aligned}$
\begin{tabular}{llll}
\hline & Odds Ratio & $\mathbf{9 5 \%}$ Confidence Interval & p \\
\hline Uric acid & 2583.8 & $147.3-45314.5$ & $<0.0001$ \\
CRP & 1187.0 & $182.1-7735.2$ & $<0.0001$ \\
\hline
\end{tabular}

$\begin{aligned} & \text { Table 4. Multi-variable analysis of the levels of uric acid and } \\
& \text { C-reactive protein }\end{aligned}$
\begin{tabular}{llll}
\hline & Odds Ratio & $\mathbf{9 5 \%}$ Confidence Interval & p \\
\hline Uric acid & 2106.4 & $14.6-304456.5$ & 0.003 \\
CRP & 16782.6 & $0.1-2742705841.6$ & 0.112 \\
\hline
\end{tabular}

patients, when compared to NCA patients. While oxidative radicals produced after the purine catabolism might induce endothelial dysfunction and CAE formation, the elevated level of SUA, as another product of this destruction, might be an independent marker for the presence of CAE. Koşar et al.(26) demonstrated that $\mathrm{CAE}$, which is attributed to atherosclerosis in $50 \%$ of cases, is a diffuse rather than a localised disease. Atherosclerosis is an inflammatory disease causing endothelial dysfunction and impaired endothelial-dependent vasodilatation(27-29). Increasing evidence shows that inflammation plays a role in all the stages of atherosclerosis. CRP, as an inflammatory protein, directly contributes to atherosclerotic process $(28)$. In addition, increased atherosclerotic load increases the CRP level. CRP is deposited in the intima of early atherosclerotic lesions and is chemotactic for monocytes (28). CRP plays a role in the early atherogenesis through the early monocyte. Numerous trials clearly demonstrated that the increased levels of CRP increases cardiovascular risk(26-32), and are of predictive value in development of diabetes and hypertension and, stroke and myocardial infarction independent from the thickness of intima-media(26,29,30). Although the underlying inflammatory mechanisms are known in CAD, there is a little information about the role of inflammation in the pathogenesis of CAE. Given the conducted histopathological studies on this topic, postmortem histopathological results of CAE patients demonstrated the presence of a more comprehensive and severe vasculary inflammation in CAE patients than in CAD. This situation possibly includes all the vascular layers in the coronary circulation and plays a rol in pathogenesis of CAE. In a study by Turhan et al.(23) CRP levels were compared between angiographically NCA, CAD and CAE patients, and they demonstrated that CRP level was significantly higher in CAE and CAD groups than in the control group. Similarly, in our study we showed that the serum CRP levels significantly increased in the CAE patients when compared

\begin{tabular}{|c|c|c|c|c|}
\hline & \multicolumn{2}{|c|}{ 95\% Confidence Interval } & \multirow[b]{2}{*}{ Maximum } & \multirow[t]{2}{*}{$\mathbf{p}$} \\
\hline & $\begin{array}{l}\text { Area Under the } \\
\text { Curve }\end{array}$ & Minimum & & \\
\hline CRP & 0.933 & 0.894 & 0.971 & $<0.001$ \\
\hline $\mathrm{CRP}<1.4 / 1.4 \leq$ & 0.920 & 0.877 & 0.963 & $<0.001$ \\
\hline $\mathrm{CRP}<1.5 / 1.5 \leq$ & 0.930 & 0.889 & 0.971 & $<0.001$ \\
\hline $\mathrm{CRP}<1.6 / 1.6 \leq$ & 0.875 & 0.824 & 0.927 & $<0.001$ \\
\hline \multicolumn{4}{|c|}{ CRP: C-reactive protein } & \\
\hline
\end{tabular}

\begin{tabular}{|c|c|c|c|c|}
\hline & \multicolumn{3}{|c|}{ 95\% Confidence Interval } & \multirow[t]{2}{*}{$\mathbf{p}$} \\
\hline & $\begin{array}{l}\text { Area Under } \\
\text { the Curve }\end{array}$ & Minimum & Maximum & \\
\hline Uric Acid & 0.991 & 0.973 & 1.000 & $<0.001$ \\
\hline Uric Acid $<5.5 / 5.5 \leq$ & 0.945 & 0.908 & 0.982 & $<0.001$ \\
\hline Uric Acid $<6.0 / 6.0 \leq$ & 0.995 & 0.984 & 1.000 & $<0.001$ \\
\hline Uric Acid $<6.5 / 6.5 \leq$ & 0.931 & 0.892 & 0.970 & $<0.001$ \\
\hline
\end{tabular}


to the controls. This data suggests that the underlying inflammatory condition has an important role in CAE as in CAD.

In conclusion, we observed significantly higher levels of SUA and CRP in CAE patients compared to the normal population, but no significant difference was found compared to CAD patients. These results show that both CAE and CAD shared common pathophysiological mechanisms. Further studies with larger population are needed to clarify the clear roles of these markers in common pathophysiological mechanisms.

\section{Limitations}

This study has some limitations; first, the retrospective design limited our study. Second, we did not perform an analysis to assess the prognostic value of CRP and SUA in CAE. The pathogenesis of CAE and CAD is similar and most of the conducted studies in stable CAD have shown the prognostic value of these indeces(24). From this point we thought that there can be a prognostic value of these indeces in CAE patients. For filling the literature gap of this topic, prospective randomized controlled studies should be done. Third, angiography cannot evaluate the plaque burden, patients without evidence of luminal narrowing by angiography may also have plaque burden in the wall of the coronary vessels. It would be better to analyse with intravascular techniques such as ultrasound whether isolated CAE patients had evidence of atherosclerotic plaque. Forth, although the formation of CAE is a slow and chronic condition, we just evaluated a single serum CRP and SUA levels in this study.

\section{CONFLICT of INTEREST}

The authors reported no conflict of interest related to this article.

\section{REFERENCES}

1. Swaye PS, Fisher LD, Litwin P, Vignola PA, Judkins MP, Kemp HG, et al. Aneurysmal coronary artery disease. Circulation 1983;67:134-8.

2. Tunick PA, Slater J, Kronzon I, Glassman E. Discrete atherosclerotic coronary artery aneurysms: a study of 20 patients. J Am Coll Cardiol 1990;15:279-82.

3. Kruger D, Stierle U, Herrmann G, Simon R, Sheikhzadeh A. Exerciseinduced myocardial ischemia in isolated coronary artery ectasias and aneurysms ("dilated coronopathy"). J Am Coll Cardiol 1999;34:1461-70.

4. Alford WC Jr, Stoney WS, Burrus GR, Frist RA, Thomas CS Jr. Recognition and operative management of patients with arteriosclerotic coronary artery aneurysms. Ann Thorac Surg 1976;22:317-21.

5. Freedman DS, Williamson DF, Gunter EW, Byers T. Relation of serum uric acid to mortality and ischemic heart disease. The NHANES I Epidemiologic Follow-up Study. Am J Epidemiol 1995;141:637-44.

6. Fessel WJ. High uric acid as an indicator of cardiovascular disease. Independence from obesity. Am J Med 1980;68:401-4.

7. Culleton BF, Larson MG, Kannel WB, Levy D. Serum uric acid and risk for cardiovascular disease and death: the Framingham Heart Study. Ann Intern Med 1999;131:7-13.

8. Ruggiero C, Cherubini A, Ble A, Bos AJ, Maggio M, Dixit VD, et al. Uric acid and inflammatory markers. Eur Heart J 2006;27:1174-81.

9. Many A, Hubel CA, Roberts JM. Hyperuricemia and xanthine oxidase in preeclampsia, revisited. Am J Obstet Gynecol 1996;174:288-91.

10. Kato M, Hisatome I, Tomikura Y, Kotani K, Kinugawa T, Ogino K, et al. Status of endothelial dependent vasodilation in patients with hyperuricemia. Am J Cardiol 2005;96:1576-8.
11. Erdoğan D, Güllü H, Çalışkan M, Yıldırım E, Bilgi M, Ulus T, et al. Relationship of serum uric acid to measures of endothelial function and atherosclerosis in healthy adults. Int J Clin Pract 2005;59:1276-82.

12. Tavil Y, Kaya MG, Oktar SO, Şen N, Okyay K, Yazıcı HU, et al. Uric acid level and its association with carotid intima-media thickness in patients with hypertension. Atherosclerosis 2008;197:159-63.

13. Tillett WS, Francis T Jr. Serological reactions in pneumonia with a nonprotein somatic fraction of pneumococcus. J Exp Med 1930;52:561-71.

14. Calabró P, Willerson JT, Yeh ET. Inflammatory cytokines stimulated C-reactive protein production by human coronary artery smooth muscle cells. Circulation 2003;108:1930-2.

15. Yasojima K, Schwab C, McGeer EG, McGeer PL. Generation of C-reactive protein and complement components in atherosclerotic plaques. Am J Pathol 2001;158:1039-51.

16. Venugopal SK, Devaraj S, Jialal I. Macrophage conditioned medium induces the expression of C-reactive protein in human aortic endothelial cells: potential for paracrine/autocrine effects. Am J Pathol 2005;166:1265-71.

17. Glagov S, Weisenberg E, Zarins CK, Stankunavicius R, Kolettis GJ. Compensatory enlargement of human atherosclerotic coronary arteries. N Engl J Med 1987;316:1371-5.

18. Newburger JW, Takahashi M, Gerber MA, Gewitz MH, Tani LY, Burns JC, et al. Diagnosis, treatment, and long-term management of Kawasaki disease: a statement for health professionals from the Committee on Rheumatic Fever, Endocarditis and Kawasaki Disease, Council on Cardiovascular Disease in the Young, American Heart Association. Circulation 2004;110:2747-71.

19. Ross R. Atherosclerosis-an inflammatory disease. $N$ Engl J Med 1999;340:115-26.

20. Demopoulos VP, Olympios CD, Fakiolas CN, Pissimissis EG, Economides $\mathrm{NM}$, Adamopoulou E, et al. The natural history of aneurysmal coronary artery disease. Heart 1997;78:136-41.

21. Farquharson CA, Butler R, Hill A, Belch JJ, Struthers AD. Allopurinol improves endothelial dysfunction in chronic heart failure. Circulation 2002;106:221-6.

22. Jaramillo M, Naccache PH, Olivier M. Monosodium urate crystals synergize with IFN-gamma to generate macrophage nitric oxide: involvement of extracellular signal-regulated kinase $1 / 2$ and NF-kappa B. J Immunol 2004; 172:5734-42.

23. Turhan H, Erbay AR, Yasar AS, Balci M, Bicer A, Yetkin E. Comparison of c-reactive protein levels in patients with coronary artery ectasia versus patients with obstructive coronary artery disease. Am J Cardiol 2004;94:1303-6.

24. Aydin M, Tekin IO, Dogan SM, Yildirim N, Arasli M, Sayin MR, Aktop Z. The levels of tumor necrosis factor-alpha and interleukin-6 in patients with isolated coronary artery ectasia. Mediators Inflamm 2009;2009:106145.

25. Dogan A, Tuzun N, Turker Y, Akcay S, Kaya S, Ozaydin M. Matrix metalloproteinases and inflammatory markers in coronary artery ectasia: Their relationship to severity of coronary artery ectasia. Coron Artery Dis 2008;19:559-63

26. Koşar F, Sincer İ, Aksoy Y, Topal E, Çehreli S. Increased aortic stiffness in patients with coronary artery ectasia. Coron Artery Dis 2005;16:499-504.

27. Torzewski J, Torzewski M, Bowyer DE, Fröhlich M, Koenig W, Waltenberger $\mathrm{J}$, et al. C-reactive protein frequently co-localizes with the terminal complement complex in the intima of early atherosclerotic lesions of human coronary arteries. Arterioscler Thromb Vasc Biol 1998;18:1386-92.

28. Torzewski M, Rist C, Mortensen RF, Zwaka TP, Bienek M, Waltenberger $\mathrm{J}$, et al. C-reactive protein in the arterial intima: role of $\mathrm{C}$-reactive protein receptor-dependent monocyte recruitment in atherogenesis. Arterioscler Thromb Vasc Biol 2000;20:2094-9.

29. Cao JJ, Thach C, Manolio TA, Psaty BM, Kuller LH, Chaves PH, et al. C-reactive protein, carotid intima-media thickness, and incidence of ischemic stroke in the elderly: the Cardiovascular Health Study. Circulation 2003;108:166-70.

30. Curb JD, Abbott RD, Rodriguez BL, Sakkinen P, Popper JS, Yano K, et al. C-reactive protein and the future risk of thromboembolic stroke in healthy men. Circulation 2003;107:2016-20.

31. James SK, Armstrong P, Barnathan E, Califf R, Lindahl B, Siegbahn A, et al. Troponin and C-reactive protein have different relations to subsequent mortality and myocardial infarction after acute coronary syndrome: a GUSTO-IV substudy. J Am Coll Cardiol 2003;41:916-24.

32. Ockene IS, Matthews CE, Rifai N, Ridker PM, Reed G, Stanek E. Variability and classification accuracy of serial high-sensitivity C-reactive protein measurements in healthy adults. Clin Chem 2001;47:444-50. 